\title{
Perceiving the Worlds of Caryl Churchill Top Girls and Fathīyah El 'Assāl Without Masks in Relation to Dramatic and Cinematic Techniques
}

\author{
Amani Wagih Abd Al-Halim \\ Associate Professor, Faculty of \\ Arts, Cairo University, Egypt
}

\begin{abstract}
Discussing her play Top Girls, Churchill explains to Renate Klett in "Anything's Possible in the Theatre" that theatre can create illogical connections: "If you want to bring characters from the past onto the stage then you can do it, without having to find a realistic justification" (19). Both Churchill in Top Girls and El-Assal in Without Masks bring a number of women from different social classes and historical backgrounds together on stage narrating their experiences, with the aim of questioning "the relationship between the past and current social practice" (Morelli 154). Hence, Churchill's and El-Assal's dramatic technique changes the purpose of
\end{abstract}

narration from mere entertainment into that of perception. To the best of my knowledge, previous studies analyzed the two plays from a feminist perspective; therefore, this paper will adopt the semiotic approach to explore the significance of the narrative technique used by both dramatists to foster the audience/reader sense of perception rather than mere entertainment, through the employment of Brecht's V-effect. To achieve this aim, the proposed study will explore the following dramatic elements: the violation of temporal and spatial dimensions, and the employment of verbal and non-verbal techniques. 


\section{Perceiving the Worlds of Caryl Churchill Top Girls and Fathīyah El 'Assāl Without Masks in Relation to Dramatic and Cinematic Techniques}

Amani Wagih Abd Al-Halim

\section{Introduction}

The present study traces the shift from narration or the word to perception or the visual image through the study of signs (semiotics). Sign system including verbal and non-verbal codes is employed to evaluate the theatrical experience because it allows the audience to infer the meanings and relations delivered through these codes, "such a subject attracts attention: it aims at defining the way meaning is produced through the interaction of codes which are in themselves so heterogeneous" (Serge 39). As theatre semiotics is the study of signs that the dramatist uses on stage for the audience to interpret, Keir Elam chooses to describe the theatrical experience as "All that is on the stage is a sign" (7). Both Caryl Churchill and Fathīyah El "Assāl manipulate sign system to depict a host of female characters to reinforce their sufferings through visual narration that addresses the audience's sense of perception attempting to encourage their spectators to "seek alternatives beyond the play[s'] representational frame" (Cameron 157). The paper attempts to analyze the use of verbal and non-verbal signs through two techniques: Brechtian alienation technique and cinematic technique. First, the paper examines the dramatic technique of distancing the spectators to foster their sense of perception rather than mere entertainment by focusing on two Brechtian elements: the violation of temporal and spatial dimensions, and the employment of verbal (overlapping dialogues) and non-verbal (gestus) techniques. Second, the paper examines the female characters' expressions of personal dilemmas in both plays through the lenses of the camera by examining two cinematic devices, namely, close- shot and POV (Point Of View).

The present study chooses both dramatic and cinematic techniques to prove that Churchill and El 'Assāl aim to engage their spectators in the theatrical experience depending on perception, or the visual image, rather than narration, or the word.

Caryl Churchill (1938- ) is an eminent British playwright. She wrote Top Girls in 1982. Her latest play Escaped Alone written in 2015, was premiered at the Royal Court Theatre in January 2016. Fathīyah El 'Assāl (1933 - 2014) was an Egyptian writer, intellectual and activist. She had not received an educational degree due to her father's regressive mentality. However, she insisted on learning to read and write. El 'Assāl wrote Without Masks in 1981.

\section{Brechtian techniques in relation to narration for perception}

Brecht's theatre is concerned with conveying meaning through portrayal of a host of theatrical techniques on stage that would stimulate the audience's interaction and sense of perception; therefore, the purpose of his theatre is to "put the audience in a better position to understand 
the world around them, a world which is social and changeable. In this way theatre involves the politics of a sign" (Fortier 29). Hence, perception and interpretation of signs presented on stage encapsulate the audience's role in evaluating the theatrical experience. For the spectators to attain the meaning of the signs, they have to be detached from the illusion presented on stage, "the cornerstone of Brecht's theory is the Verfremdungseffekt ('alienation effect'), the technique of defamiliarizing a word, an idea, a gesture so as to enable the spectator to see or hear it afresh" (Diamond, Unmaking Mimesis 45). Therefore, the playwright has to alienate his/her audience by breaking the fourth wall which allows the actors on stage to acknowledge the presence of their audiences and in turn to engage them in the theatrical experience (Davis 86). Accordingly, Churchill and El 'Assāl use many alienation techniques such as violation of temporal and spatial dimensions, the employment of overlapping dialogues and 'Gestus'.

\subsection{Violation of temporal and spatial dimensions}

Both Churchill and El 'Assāl violate the Aristotelian concept of temporal unity by narrating past events while simultaneously displaying present events to reinforce the alienation effect and to stimulate the audience's sense of perception. This is done by following three techniques: the rocking chair movement, portrayal of dramatic conflict through flashbacks, and unfolding suppressed emotions stored in the subconscious.

First, both playwrights employ the rocking-chair technique to move from the present to the past and vice versa, and throughout the process, they manage to provide the audience with some details about their female characters.

In Top Girls, Churchill resorts to the rocking chair technique when she keeps shifting the time span of the acts. The time of the action is not introduced to the audience in the first two acts. Throughout the course of Act One, Churchill provides the spectators with few details from which they realize that they are watching the present and the past running parallel to one another. Marlene, a contemporary figure is holding a female gathering to celebrate her promotion. Her female friends are paragons of different cultures, classes and periods of time; they are a collection of fictive and real characters: Isabella Bird, a Scottish explorer and traveler from the nineteenth century; Lady Nijo, a Japanese courtesan from the thirteenth century; Pope Joan, a German legendary figure from the ninth century; Dull Gret, a Flemish folkloric figure from the painting of Brueghel in the sixteenth century; and finally Patient Griselda, a fictive figure from Chaucer's The Canterbury Tales in the fourteenth century. The world of fantasy provided by merging the present and the past pinpoints the futility of the female protagonists' experiences because they are introduced as pioneers in achieving independence in their patriarchal societies; however, they turn out to be conforming to male superiority.

In Act Two time is also not identified. However, the audience can conclude that Churchill has shifted the time wheel to the present in which Marlene's eccentricity appears at work to highlight Marlene's adoption of patriarchal standards in the ruthless world of business. Unlike the indefinite span of time in the first two acts, Act Three flashes back one year as specified by the stage directions, "A year 
earlier. Sunday evening" ( $T G$ 121). Then the act and the play ends with "a little girl's [Angie] nightmare of the future" (Brown 117). Though the events in Act Three take place in the past, Angie's frightful shriek extends to the present and may be to the future as well. It foreshadows the tyrannical dominance of the materialistic world as indicated by Marlene's attitude, especially in Act Two, and the urgent need to change or else it will affect the future.

Similarly, in Without Masks, El 'Assāl employs the same rocking chair technique to highlight the fact that the suffering of females in patriarchal communities has not changed throughout different periods of time. In Act One, the spectators are introduced to a contemporary authoress and at the same time the stage directions refer to three disparate ages on stage: the Stone Age, the Feudal and the Modern ones, in which a male and a female dancer are performing three different dances denoting each era. Then four female characters start emerging out of the authoress' self: a middle class young girl in her twenties; a bourgeois divorced woman in her thirties; a wealthy housewife in her thirties as well; and a poor widow in her fifties. Throughout the course of the play, the five female characters (including the authoress) are engaged in a process of chronological shifts moving from the present to the past and back to the present. Both time periods are represented running parallel to one another. The female protagonists used to suffer from males' oppression in the past and are still tormented. However, the difference between both plays is that Churchill's female characters surrender or adopt the same oppressive practices of their societies, whereas
El 'Assāl's revolt and decide to find a solution to their common plight. The different female characters in El 'Assāl's play join hands in the final scene to overcome male oppression and suppressive social norms; however, in Churchill's the play ends with each female character living in her own world.

Second, Churchill and El 'Assāl violate the Aristotelian tradition which "handles the temporal unfolding of events by means of turning points" (Gombrich 40). In other words, dramatic conflicts experienced by the female protagonists in both plays flow spontaneously in the course of the plays, "There is neither the temporal unfolding of events nor the capturing of a moment as the turning point" because "all times and spaces may appear side by side" (Cicekoglu 128), thus denoting the fact that the conflicts presented on stage can arise in any place and at any time.

The dramatic conflicts of female protagonists in the plays can be traced in the flashback technique deployed by both Churchill and El 'Assāl. In Top Girls, Act Three stands for the climax, and ironically the moment of realization does not belong to Marlene or any of her imaginary female friends, but rather to Angie and the spectators. This moment of revelation invites them to reconsider the action presented on stage, where Angie is found out to be Marlene's daughter whom she has abandoned for the sake of her glorious future; in addition, the real self of Marlene as an oppressive capitalist is unfolded. The play ends with Angie's one word "Frightening.. Frightening" (TG 137) thus describing the ugly side of the world to which her mother belongs. Marlene has not achieved her success in the business world of men as an individual, or an independent female, but rather as a female 
adopting the males' criteria. She has sacrificed her motherhood and sisterhood to pave her tough way in the world of business, which she cannot relinquish for any reason. Her overdrinking in Acts One and Three stresses the point that she is not happy despite the fact that she has achieved her dream, as Jay King explains "Marlene has learned nothing, and neither will she pass anything on. Marlene's extreme individualism has brought her success, but for her only. It does not even extend to her own daughter" (79) because Angie is different from her. Her inability to resemble her biological mother is indicated by the stage directions when she falls asleep in Marlene's office, her place of power and victory, and is reinforced by Marlene's opinion of her "She's a bit thick. She's a bit funny... She's not going to make it" (TG 120).

The flashback technique is extensively used in Without Masks to present the conflicts of the female protagonists. In Act Two, the characters start to unfold their real selves. Unlike Marlene in Top Girls, the female characters in Without Masks confront their dilemmas that they previously denied in Act One. For example, the wealthy wife confesses her adulterous relationship with her cousin. She even refuses to ask for divorce and to marry her lover because she is leading a luxurious life with her husband, which she will never renounce. She succinctly argues that she needs love from her lover to satisfy her physical needs which are either denied or brutally fulfilled by her husband. Nehad Selaiha praises El 'Assāl's skillful manipulation of this issue, "Indeed, no other Egyptian playwright, male or female, has celebrated with such gusto the female body and its physical appetites and needs" (634):
The wife: I wanted to be faithful to my husband, but I couldn't. Once I have seen you, cousin, I hold you and won't let go.

The lover: You can't go on deceiving yourself and your husband; you must ask for divorce.

The wife: Divorce?

The lover: Yes, divorce and we'll get married. I can't stand it anymore!... We must live together...

The wife: Do you want me to get divorced and to be deprived of my paradise? (WM 206-207)

Third, past experiences and emotions are stored in the subconscious. According to Constantin Stanislavski, the subconscious represents the "inner mechanism" or the "uncontrollable complex of emotions" that can be "turned on intentionally" by what he termed as the 'emotional memory' which helps in bringing past experiences back to be relived (qtd. in Moore 220). The female protagonists in both plays are engaged in female gatherings that unlock their emotional memories allowing their suppressed emotions to overflow, thus offering the audience the chance to perceive and evaluate the experiences on stage. In Top Girls and Without Masks, they start to unfold the secrets of their lives; the technique implemented by both dramatists corresponds to the stream of consciousness used in prose writing. Emotions cumulated in the protagonists' subconscious are unveiled in a process of confession.

Lady Nijo in Top Girls admits the fact that she has never been happy though she strongly believes in her assigned role as 
the Emperor's courtesan and brags of being his favorite, "The first half of my life was all sin and the second all repentance... I was very unhappy. It hurts to remember" (TG 59). Under the effect of heavy drinking, Marlene shifts from celebrating her success "We've all come a long way. To our courage and way we changed our lives and our extraordinary achievements" (TG 67) to reveal the workings of her subconscious and admits that her imaginary friends and herself have not attained happiness despite their belief in their success in the world of men, "Oh God, why are we so miserable?" ( $T G 72)$. The female protagonists in the play do not rebel or change the world; on the contrary, they have established their positions in the world of men by conforming to the rules set by their patriarchal societies.

Keith Peacock contends that "in order to attain that status... each either gave up children and family relationships or adopted masculine behavior" (94). However, the arrival of Patient Griselda at the end of Act One partially argues against Peacock's claim because the other female guests willingly gave up their children and endorsed patriarchal norms. Griselda is the epitome of obedience and humiliation. Though Marlene and her friends object to her utter compliance, they are unconsciously performing her role. Pope Joan was disguised in men's clothes (she enjoyed being treated as a Pope); Isabella Bird had to obey her father and felt lost after his death (she used to live in his shadow); Lady Nijo had to obey the Emperor in everything (she accepted humiliation and male oppression); Dull Gret the rebellious figure who led an army of women was dressed in male military armour (she felt protected in man's costume); and Marlene herself adopted male conventions in the world of business to be able to succeed (she could not achieve her success except after following man's standards). By the end of Griselda's narration, the whole gathering falls in confusion; "the already strained dinner party has disintegrated into chaos and confusion, with Marlene drinking heavily, Lady Nijo crying, Joan reciting garbled Latin, and Isabella continuing to relive past moments of glory" (Cameron 160). The confusion of the female guests stands for their confrontation with their real selves realizing the illusions of their success.

In Without Masks the suppressed emotions in the subconscious flow impulsively. The authoress unfolds the horrible experience of her circumcision when she was a little girl:

I was a little girl.. And life was beautiful.. One day in the early morning I woke up from lovely dreams to find a host of people.. There were many people who hid the light of the morning.. They were huge and heavy and my little body was numbed under their pressures.. They seized me and I was looking terrified as a victim, ready for the butcher holding the knife... They slaughtered me... I became half human.. Who would need a half human except if he is a half human as well.. Who would need a body without sensation except if he is also a body without feelings? ( $W M$ 193, 194)

This shift or temporal violation is counterbalanced by spatial violation through the portrayal of different locations on stage. The lack of demarcation between time periods and settings in both plays 
establishes the world of fantasy and stimulates the audience's alertness to the significance of this violation. Being emotionally detached from the action presented on stage, the spectators are able to rethink of the theatrical experience and to reconsider their own beliefs.

In Top Girls, Churchill provides few details about the setting of her play. Act One takes place in a "Restaurant. Tables set for dinner with white tablecloth. Six places. Marlene and Waitress" (TG 55). Because this setting fits any place and any time, Churchill gives her audience the chance to predict or expect the time of action and the guests. However, she intensifies the spectators' sense of confusion and attentiveness by presenting a world of fantasy on stage when Marlene starts to receive her imaginary friends. The setting described in Act Three stands in sharp contrast with that of Act One: "Joyce's kitchen. Joyce, Angie and Marlene. Marlene is taking presents out of a bright carrier bag. Angie has already opened a box of chocolate" ( $T G$ 121). Despite the fact that both scenes denote celebrations, the sense of exhilaration is soon shattered in Act One, whereas in Act Three it is sustained for sometime before it is equally crushed when Marlene and Joyce start their debate. Furthermore, the business like atmosphere denoted by the setting in Act One contrasts with the cozy atmosphere indicated by the kitchen in Act Three. In addition, the setting of Act One presents a world of fantasy that can never exist except in the imagination of Marlene herself, whereas in Act Three the setting is realistic and is, therefore, stored in Marlene's subconscious.

Though Act Two lacks any indication of time taking place in "an eternal present that further disorients the audience"
(Brown 107), the setting combines equal shares from the two other acts. It is as realistic as Act Three but does not provide a comfortable atmosphere; and it does not present a world of fantasy as Act One does but rather introduces a cold and harsh atmosphere. The setting takes place first in Marlene's office Top Girls Employment Agency. It is the place that stands for her power and success, and in which she practices her anomalous behavior towards her employees. Second, the setting moves to Joyce's backyard that stresses the sense of isolation of both Joyce and Angie. Kate Peacock contends that it "creates a much bleaker impression of the materialistic lives of Marlene and her employees and the socially deprived world inhabited by Joyce and Angie" (94). As the materialistic world of business isolates Marlene in her ivory tower away from others, lack of communication between Joyce and Angie divorces them from each other and from their surroundings.

In Without Masks, El 'Assāl violates spatial dimensions by maintaining the world of fantasy on stage even though the characters and events are realistic. The female characters join each other in exploring the setting that belongs to each of them. For example, the wife asks her friends to actually live in her place and to witness the course of the events:

Light on the wife's house. The wife proceeds leading them in.

The wife: Come on..Come and live with me.

The three females join the authoress and enter the house. They are going to participate in the action from now on.

The authoress: Is this your house? 
The wife: Yes, the house that my second husband gave me. (WM 197)

El 'Assāl's description of the spaces on stage coincides with Ute Holl's explanation of the techniques of spatial violation. She uses "shading of the lights", "sharp outlines" of some parts and "quietness" of others set against "the vehement movement of others" that all contribute in "play[ing] on the keyboard of our mind" (Holl 25). Her aim, therefore, is to move beneath the conscious perception of the spectators and thus to stimulate their intellectual and perceptive abilities:

Darkness. Then gradual light showing a place from the age of servitude. Curtain backstage showing a house from previous eras. A mashrabiya. The wife looks worried... Light inside the house shows terrible cramming of electronic devices... The wife speaks to the other female characters that hide backstage. (WM 198)

The interplay of different shades of light, the intense movements of the wife set against the quietness of the other characters who move back to the décor of the house activates the spectators' sense of perception and motivates them to draw their own inferences that members of this female gathering will achieve a kind of consensus. The purpose of temporal and spatial violation is therefore to "force audience members to reevaluate the play[s] from another perspective, usually an objective, future perspective rather than an internal, 'in-the-moment' point of view" (King 16). Thus both Churchill and El 'Assāl succeed in distancing their audience and maintaining the status of spectatorship. The audience thinks as an outsider without getting emotionally involved in the action. In other words, the theatrical experience is perceived, reconsidered, evaluated by drawing similarities between the present and the past (time and space) presented on stage and related to future possibilities.

\subsection{Overlapping dialogues}

Though Churchill in Top Girls and El 'Assāl in Without Masks employ overlapping dialogues as a technique targeting the alienation effect, the two plays achieve the same purpose in two different ways. While overlapping dialogues in Churchill's manifest the lack of communication and unity between the female characters by using multi-voiced narration, El 'Assāl's reveal a rich sense of communication and unity presented by collaborative narration.

Throughout Churchill's play, the female characters "tend to talk at each other, rather than with each other, and dialogue overlaps to the point where it becomes nigh incomprehensible" (King 71). All of them including Marlene and Joyce are incapable of communicating and in turn of achieving unity. Churchill deploys the multi-voiced narration technique in Acts One and Three to reinforce the inability of her characters to listen to each other; every one of them lives in her own world and rejects feeling for others. Amelia Kritzer succinctly elucidates that "the historical women remain locked in their own, singular perspectives" (143) and since they belong to different cultures and are ignorant of the others' cultures, they misjudge each other's behavior and at the end fail to communicate. 
While Isabella remembers the death of her father and her feelings of loss and grief in the opening scene, the other ladies decline sharing her emotions:

Isabella: Grief always overwhelmed me at the time.

Marlene: What I fancy is a rare steak. Gret?

Isabella: I am of course a member of the......./ Church of England.

Gret: potatoes

Marlene: I haven't been to church for years..... I like Christmas carols.

Isabella: Good works matter more than church attendance...

Marlene: Were your travels just a penance? Avocado vinaigrette. Didn't you......../enjoy yourself?

Joan: Nothing to start for me, thank you. (TG 59) [The spaces and slashes in the text mark points of interruptions according to Churchill]

The only feature that these female characters share is suffering from patriarchal oppression. Despite suffering from the same plight, they fail to unite. For example, when Pope Joan narrates her suffering while giving birth in a narrow street and her torture when discovered that she was a woman Pope, the other characters respond by laughing at her situation rather than sympathizing with her.

According to Rebecca Cameron "Churchill draws attention to the fissures and frictions within her gathering of great women from history, rather than presenting them as a cohesive whole"
(157) to highlight the dominance of materialistic values over the humanistic ones. Earlier in the scene, Marlene makes fun of Joan being Pope when she is asked about her promotion "Well it's not Pope but it is managing director" ( $T G$ 67). She also teases Nijo calling the Emperor "sod" (80) and Griselda describing the Marquis as "bonkers" (77) and "monster" (79). She refuses to listen to Griselda so as not to identify herself with the latter's acceptance of the oppressive tactics of male superiority; she excuses herself "I can't stand this. I'm going for a pee" (TG 77). Deep within, Marlene is conscious of the fact that she is adopting masculine norms, views and behavior to succeed in the world of business; however she pretends that she is preserving her feminine independence. She is aware that "unless women, in the interests of economic and professional advancement are prepared to make sacrifices, particularly of the domestic and maternal kind, and espouse masculinist values then they do not 'get on'" (Aston 2003, 22). Lack of communication that marks the relationship between the female characters leads them to burst in fits of weird behavior at the end of Act One: "Nijo is laughing and crying; Joan gets up and is sick in a corner; Marlene is drinking Isabella's brandy" ( $T G$ 83) and Isabella continues narrating her adventures while nobody is listening.

The same pattern of overlapping dialogues is repeated in Act Three. Marlene and her sister Joyce also lose all possible means of communication:

Joyce: You can come and see Angie any time you like, I'm not stopping you....../ You know where we are. You're the...........

Marlene: Ta ever so. 
Joyce: one went away, not me. I'm right here where I was. (TG 124)

Throughout Act Three, their inability to communicate and comprehend each other results in frustration, blockage to mutual understanding, and exchanging accusations leading to "near-cacophonic vocalizations" (Diamond, "Bodies" 189).

Act Two does not apply the technique of overlapping dialogue. However, it consists of a series of single line dialogues to highlight the business like quality of scenes One and Three showing Marlene at work in the employment agency, and the lack of mutual understanding of a normal mother-daughter relationship between Joyce and Angie in scene Two.

The employment of overlapping dialogue produced by multiple voices activates the audience's sense of perception and alertness "as it engages the audience in an unconventionally vivid dialogue with the performing narrator on stage... [It] enhances the audience's role in the production of meaning" (Kurdi 227). The audience can conclude that the female characters in Churchill's play have lost all means of communication and empathy towards each other in various types of relationships between friends, sisters, employer-employee, aunt-niece and worst of all mother-daughter.

El 'Assāl manipulates the technique of overlapping dialogues through collaborative narration or interactive conversations between her female characters. Like the female characters in Churchill's play, in Without Masks the females are equally oppressed by the norms of the patriarchal society. According to Nehad Selaiha, El 'Assāl repeats the same pattern used in her other plays by portraying "a confessional mode in multiple voices, all female and all oppressed, that refracts the dramatic focus among them and projects their stories as different manifestations of female oppression" (634). However, their shared experience of suffering unites them together. In other words, "overlaps enhance rapport rather than displaying status differences" (Eder 232). In their collaborative speeches, they encourage each other to express themselves honestly in the form of "a chain of influences... with one speaker shaping the memory of a listener, who in turn, becomes a speaker who can influence another listener" (Coman 131). Being troubled and isolated characters as in Top Girls, the female figures in El 'Assāl's play delivering their extended narration "in front of other characters, were afforded opportunities to express what could not be accommodated through inter-character exchanges of dialogue" (Jordan 228). In other words, the women in the play invigorate each other to narrate their dilemmas and to unveil their real selves; confessions that they would be reluctant to face alone. This sequence of interactive conversations/dialogues leads to one cohesive whole meaning that the characters complement each other:

The authoress: And we descended from our place beside men; and our history was forged.

All: Our history was forged.

The authoress: We became a curse.

All: But desired

The authoress: We were tainted as a venomous viper.

All: But wanted 
The authoress: We became wombs giving birth

All: to masters and slaves. (WM 191)

This sense of solidarity is further enriched by the "similar point of view" and "shared attitudes and perceptions" (Eder 226) of the female characters. In other words, collaborative talk leads to cohesiveness or unity between speakers/listeners. When the girl tells her lover that she will marry a rich man, but remains with him at the same time, the other female characters share the same stance of objection:

The authoress: I didn't tell you to do this

The girl: But you didn't tell me what else can I do?

All other characters surround the girl as in a trial.

The authoress: We showed you the truth..The truth without lies.

The girl: And what is the use of all this?... I'll marry someone whom I don't love and meet my lover secretly.. in darkness.. the circumstances are the same, nothing has changed.

The wife: No.. No, don't do this..If you and your lover do this, we will remain as we are.. Frightened

The widow: Scared

The divorced: Lost

The authoress: Impossible.. Impossible. (WM 254)

Another strategy of storytelling within collaborative narration in El 'Assāl's play is expressing excitement during the process of narration, as Donna Eder contends "by expressing excitement about the story telling of an event, the conarrator indicates that the event is of considerable interest and deserves narration" (228). Consideration and observance of others among the female characters in the play strengthen collaborative narration and pave the way to their cohesiveness:

The authoress: She [the widow] said loneliness is difficult and she brought up her children alone, by herself.

The widow: Yes, sis, you are right. By myself, by myself, my whole life I was by myself.

The authoress: Therefore, I am proud of you and will proudly write about you.

The girl patting on the widow's shoulder

The girl: You remind me of my mother..Living with my father and feels like a widow.

The widow (shocked): Living with your father and feels like a widow? How come?

The girl: What do you call a woman who doesn't have the right to lead her life?

The wife (resentful): What is this nonsense?

The divorced (sarcastically to the wife): You don't like her words because you feel it, don't you? (WM 151)

The interactive conversation between the female characters in the play enhances their collaborative narration. Unlike the 
case in Top Girls, the females in Without Masks listen to and understand each other because they confront their problems and challenge their weaknesses, whereas Churchill's characters live in the illusion of success and therefore fail to admit their flaws while being conscious of them.

El 'Assāl 's female protagonists collaborate to overcome their failings as indicated at the end of the play:

The authoress holds the hands of her female characters and joins their hands together. The young man and the girl start singing with the rest of the characters.

All: Truth is not divided.. Freedom is not divided.. Truth is not divided.. Freedom is not divided..Both of us are one.. Male and female are one..One human being.. One human being. (WM 258)

\subsection{Gestus}

Brecht defined 'gestus' as "a gesture, a word, an action, a tableau by which, separately or in series, the social attitudes encoded in the play text become visible to the spectator. A gest becomes social when it allows conclusions to be drawn about social circumstances" (105). According to the definition, gestus as a theatrical technique enhances narration for perception and entails audience's participation. Marvin Carlson explains the difference between gestus and gesture; he contends that "gesture reveals subjective personal states, while Gestus is always social- it makes corporal and visible the relationships between persons" (Carlson 384 emphasis in the original). Carlson's distinction implies that gestus delivers a message and addresses the faculty of perception. Both plays host a variety of sentient gestus presented in tableaux that invite the spectators to consider and evaluate their theatrical experience.

Act Two scene one in Top Girls presents one of the tableaux that manifests both visible and aural gestus. The audience can perceive in more details the uncompassionate Marlene. Now at work in the employment agency, she is interviewing an applicant, Jeannine, supposedly to help her find a job. She starts by commenting on Jeannine's mediocre marks in courses, concluding that the applicant is not brilliant enough; an assumption that leads Jeannine to remind Marlene that she "wanted to go to work" (TG 84). Throughout the interview, Marlene learns that Jeannine is working in a secretarial position and has no opportunities of advancement, so she needs another well-paying job to save money for her expected marriage. Marlene and Jeannine are portrayed as two opposite characters. Marlene is indulged in the world of business; she has sacrificed her motherly and familial relationships for the sake of her career. On the other hand, Jeannine plans to get married and to lead a normal familial life. This explains Marlene's attitude with Jeannine being characterized by utter aggressiveness, haughtiness and hyper professionalism; she devalues Jeannine's aspirations to work in an advertising agency, to travel and to acquire higher position at work. Marlene asks Jeannine not to mention her marriage plans because this will affect her employment chances. She could not believe that a woman can strike a balance between her career and her family life; it seems that she is giving justifications for herself when she has abandoned her daughter, her sister and her mother for the 
sake of her career prospects. At the end of the interview, Marlene's egocentricity drives her to imply to Jeannine that she cares more for her agency, "If I send you that means I'm putting myself on the line for you" (TG 87). The portrayal of Marlene at work leads the audience to ponder about the relation between success in career and family life which is the core message of the play.

The first scene in Without Masks presents a visual gestus and conforms to the Brechtian definition in relation to the distancing/alienation effect as "real life presented on stage is never a literal or realistic presentation but a symbolic or hypothetical representation. The distance between stage life and real life is always great, and such distance is maintained from the beginning to the end of the play" (45). As in Top Girls, the opening scene in El 'Assāl's play reveals a world of fantasy that cannot exist in real life, but stands for the changes in the male-female relationship.

In Act One scene one the authoress is presented on stage; at the beginning she could not speak and then she bursts out enthusiastically that "Many years ago, males and females used to be one..one entity..one creature..one human being" (WM 139). The stage props stand for three different epochs: the Stone Age, Feudal Age and Modern Age. A male and a female dancer, coming out of the Stone Age background, start to perform a scene that indicates love and mutual understanding and the authoress comments on their elegant movements "they were two souls in one body.. They used to share their happiness and sadness.. even the dangers were equally shared" ( $W M$ 139). Gradually the dancers are separated when the male dancer claims his superiority; then he starts to subdue and humiliate his female partner in a brutal dance; "Now we conceive of a theatre in which the human body may speak and write through movement and words" (Bryant-Bertail 213 emphasis in original). The authoress then implores her thoughts to bring out other oppressed females to be engaged in a collective thinking process trying to find a solution to their common problem: "I want to think with their minds; listen with their ears and speak with their tongues" ( $W M$ 143). Through this surrealist presentation the audience is invited to rethink of the oppressive tactics imposed on females in the patriarchal society and to find a solution to the problem.

The audience of both plays achieves the conclusion that the characters portrayed on stage represent "their classes and social ideologies" (Silberman 182), yet none of them can be regarded as a positive role model. All of the female characters suffer from oppression and marginalization; some of them fit in such frame and are accustomed to this type of living such as Patient Griselda, Lady Nijo, Joyce and even Marlene whose success "does not really challenge patriarchal authority but appropriates it" (Marohl 382). These females are not rebelling against their oppressive societies despite their claims of superiority and independence, like Marlene and the divorced, are false. Other females aspire to change the ways of living and treatment such as the girl and Angie: the girl is fully conscious of the necessity to change and she starts by rebelling against patriarchal oppression. On the other hand, Angie is still experiencing the process of the ongoing change; though she is not regarded brilliant enough according to the criteria of the materialistic world, she 
starts to gain experience and her aural gestus "Frightening" ( $T G$ 137) that closes the play can be considered her first step to knowledge. Another type of female characters has secretly rebelled against the patriarchal constraints such as the wife and the widow.

At the end of Act One in Top Girls, Pope Joan could not stand Lady Nijo's sobbing for the death of her father and the Emperor that makes her feel lost "I hid in the room with his coffin, then I couldn't find where I'd left my shoes, I ran after the funeral procession in bare feet, I couldn't keep up" (TG 80). It seems that the ladies are accustomed to oppressive tactics without which they are confused, not knowing what to do. Nijo gives a shocking example of how she was treated by the Emperor: she was eighteen and attended an occasion in which a "special rice gruel" (TG 80) was served and after stirring the gruel with a stick, the Emperor started beating his women "across the loins" ( $T G$ 80 ) using the stick so that they would give birth to males and not females. Nijo comments on this humiliating behavior stating "that's normal" ( $T G$ 80). Griselda equally accepts degradation practiced upon her by the Marquis earlier in the play, when he deprived her of her children and ordered her to go, almost naked, back to her father's home "I took off my clothes. He let me keep a slip so he wouldn't be shamed. And I walked home barefoot. My father came out in tears. Everyone is crying except me" (TG 79). Elin Diamond argues that Joan's act of vomiting, after failing to continue her recital in Latin, "is a sentient gestus announcing the female body's revulsion at the mystification and misogyny of Western religion-whose authority Joan nevertheless impersonates" $(1997,89)$. In fact, Joan's reflexive act of visual gestus stands for her repugnance of the deviant practices against females exercised by the society at large and not specifically in religion; her last utterances before becoming sick are incomprehensible babbling related to death, empty breasts, and she concludes by "splendorem purpureai" (purple splendor) (TG 82). Joan's message is directed to the patriarchal world that suppresses females and incarcerates them in certain roles to perform. Churchill calls for a society in which "people can be in touch with their feelings, and in control of their lives...the kind of society she would like: decentralized, non-authoritarian...a society in which people can be in touch with their feelings" (Aston," Feeling the Loss" 581).

Similarly Marlene's visual gestus regarding her act of heavy drinking highlights her loss in finding a solution to her dilemma. In other words, she is not satisfied with her life despite achieving her successful promotion at the expense of a male co-worker.

Gestus does not refer to gestures only, but also "facial and vocal expression and the attitude or attitudes that these express" (Epp 291). Marlene's materialistic nature appalls Angie at the end of the play when she bursts in a frightful cry, an aural gestus, "the daughter stumbles from her bed to center stage in the last image of the play, and her final cry is a terrifying shriek of isolation and need" (Keyssar 215). Angie needs love and protection that she cannot find in her relationship with either Joyce or Marlene.

The same scream of aural and visual gestus is released by the wife in Without Masks. She cannot endure leading a double life trying to please both her 
husband and her lover; she feels split into two halves "and every half cries, yells at me saying no.. no.. you are deceiving yourself.. you are betraying yourself... yes I'm betraying myself.. I'm unfaithful.. I'm dishonest" (WM 209). Once she confronts herself and her society at the same time, she takes off her yellow wig and throws it at the authoress:

From now on I won't put on a yellow wig, nor glistening accessories, nor glittering dresses..to satisfy my husband so that I won't be divorced.. from now on I won't put on corset to shape my figure so that my lover would see me as young as I used to be..No..No.. My hair is curly and grey, here it is.. My body is plump and flabby, here it is.. This is me.. I refuse working by electricity and technology..I refuse..I refuse.. I'm not like this and won't be that person again. (WM 210)

The wife taking off her wig and refusing to be confined within a certain frame to please her men stands for her abhorrence of the oppressive norms in the male dominating society. Gestus whether emitted intentionally as the wife's case or unintentionally as Pope Joan's indicates "the character's social attitude and way of behaving" in order to pinpoint "the relations among people" (Fortier 27).

Similarly when the female characters encircle the authoress to express their disgust and inability to endure these oppressions that is both kinesthetic and aural gestus, they motivate the spectators to reevaluate their position and their social norms. They give examples of the relation between oppressor (males) and oppressed (females):
The female characters surround the authoress and encircle her closely forming a closed circle.

The divorced: She obeys the father The girl: She obeys the brother The widow: She obeys the son The girl: She just obeys..obeys only

Moving in the circle around her

The wife: At home.. she obeys only The widow: On the field.. she obeys only

The wife: In bed.. she obeys only

The divorced: At work.. she obeys only

The girl: At the factory.. she obeys only. (WM 183)

Unlike the female characters in Churchill's play, El 'Assāl's females agree and collaborate to try to find a solution to their dilemmas. They are not addressing the authoress, but the society at large; and the representatives of their society is the audience. Marvin Carlson in Theories of the Theatre stresses the role of the audience for a complete theatrical experience:

There is the pleasure of discovery, of analyzing the signs of performance, of invention (when the spectator finds her own meanings for the theatrical signs), of identification, of experiencing temporally the impossible or the forbidden, and finally there is the total pleasure suggested by the Indian rasa 'the union of all affective elements, plus the distancing that gives peace'. (510)

Though the audience can evaluate the performance and interpret the signs 
presented on stage, he/she is emotionally alienated or detached from the characters on stage because the plays aim to examine situations rather than characters.

Professor Elaine Aston and playwright Sarah Daniels gave Caryl Churchill the title of 'Picasso' of British theatre because of her skill in producing a new meaning from bringing incoherent fragmented characters together like in the art of 'collage':

Collage had long been a technique in the crafts and popular arts in both Western and other cultural traditions when, in the second decade of the $20^{\text {th }}$ century, Pablo Picasso and Georges Braque turned to this technique to pursue Cubist experiments in dismantling traditional realistic representation, using found materials and assembling fragmented elements through a method of juxtaposition. (Raaberg 154)

Collage transfers materials from one context to another; in other words it is "a work of art made by pasting materials... and pictures onto a surface" (Gerry Charm) giving it a second life or another identity.
Both Churchill and El 'Assāl apply the technique of collage by bringing together an assortment of contradictory female characters who share the same experience of oppression and marginalization by their male-dominated societies. Each female presented on stage retains her social standard and cultural ideology; however, in

El 'Assāl's play the female characters manage to merge, whereas in Churchill's play they fail to achieve solidarity, "we understand identity claims as rallying points for political mobilization, they appear to hold out, the promise of unity, solidarity and universality" (Butler 140); however, they end up in chaos, confusion and perplexity. Similar to the art of collage, the discrepancy between the females in both plays like the "splashing and rubbing colors, primary ones dominating; lines crisscross and overlap; and images exceed the frame not only laterally and horizontally but also vertically like an opaque palimpsest in layers and covering one another, interrupting each other's surfaces" (Cambre 70) motivates imagination and activates perception. According to the above definition, the technique of collage used in visual art and the theatrical technique used by both playwrights can be summed up in the following table:

\begin{tabular}{|c|c|}
\hline Collage technique & Theatrical technique \\
\hline splashing and rubbing colors & costumes \\
\hline dominance of primary colors & dominance of male superiority \\
\hline lines of colors crisscross and overlap & $\begin{array}{c}\text { lines of speech crisscross and dialogues } \\
\text { overlap }\end{array}$ \\
\hline $\begin{array}{l}\text { images interrupt each other in all } \\
\text { directions }\end{array}$ & $\begin{array}{l}\text { female characters embrace many } \\
\text { contradictions }\end{array}$ \\
\hline
\end{tabular}


According to Roland Barthes and Patrick Pavis, the costume is a social sign that points to the social class and culture of the character (Fortier 30). In Top Girls, Lady Nijo, for example, wears "raw silk pleated trousers and a seven-layered gown in shades of red, and two outer garments, yellow lined with green and a light...green jacket" ( $T G$ 62); a costume that makes the audience realize her status as a Japanese courtesan, "as each successive character enters in costume... the audience becomes aware, perhaps only dimly, of the process of history the costumes represent" (Marohl 383). Most probably Marlene wears attire that suits her job as an expected managing director; it "represents the most recent example, the power dressed tailored suit worn by the 1980s female executive" (Peacock 94). She pretends to maintain her strong independence and therefore she refuses to wear trousers "I don't wear trousers in the office...../I could but I don't" ( $T G$ 62). Ironically, Marlene does not want to dress like men, but she is oppressing others more than men. Similarly, the divorced in Without Masks is described to be dressed up carelessly without make up as if she does not pay much attention to her appearance or rather to the opinions of others. She claims to be an independent woman who has asked for divorce because her marital relationship has changed; it is no more based on mutual love and understanding. However, the divorced soon unfolds the reason for her divorce when her husband confronts her with the true self that she tries to hide. All of the female characters narrate their painful experiences and sufferings from male oppression. Their fractured speeches and overlapping dialogues stress their psychological instability because of their exposure to suppression and humiliation.
While the women in Top Girls retain their differences and contradictions till the end, failing as a "grand synthesis of ...trans historical experiences, strengths, and strategies of resistance" to inspire "the struggling women of the present" (Kritzer 143), their counterparts in Without Masks manage to collaborate and join hands to face oppression, despite their differences.

\section{Cinematic techniques}

John Kelly explicates the relation between cinema and drama; both are forms of art that create virtual situations, and as cinema "communicates in images (which can be seen and heard) in order to create an illusion or a virtuality" drama "create[s] a virtual history" (427). Both cinema and drama present virtual states depending on the artistic image that delivers the message to the audience more than any other element. Therefore, it is the image that communicates with the audience who in turn interacts with.

\subsection{Close shot}

Close shots reveal details of the subject and highlight emotions of a character, "a real close-up of an actor is about going in for an emotional reason that you can't get any other way" (Schrader 60). In Top Girls, Griselda's account of her suffering from the Marquis' disgracing attitude towards her can be a good example of the close-up technique. Griselda gives a number of visual images that address the audience's sense of imagination and perception. She starts by underestimating herself as a poor peasant girl who looks after a flock of sheep, and he is the wealthy Marquis, the "absolute lord of life and death" (TG 74); then she describes the Marquis' proposal of marriage referring to "the wedding day", "the procession", "our 
cottage", and finally her promise to "obey him in everything" ( $T G$ 75). This visual tableau prepares the audience to her utter submission to her husband's aberrant behavior by depriving her of her children because people could not accept the fact that his heirs are the children of a peasant! Griselda's account does not arouse any emotions within her, except when she was reunited with her children after they grew up, "Well I fainted. Then I cried and kissed the children" (TG 79). Everyone in her village was crying for seeing her so humiliated, except herself, "My father came out in tears...../ Everyone was crying except me" (TG 78). In fact the descriptive details of her narration motivate the audience's sense of perception and drive him/her to scrutinize Griselda's story to reevaluate this experience.

As in Churchill's play, in El 'Assāl's Without Masks the female protagonists are portrayed in a close-up fashion to explore their inner feelings and their sense of grief, "in the psychic terrains inhabited by the protagonists... loss and grief appear to be dominant. Performing usually parts of women's life-stories in retrospect, they present memories of traumatic experience" (Heddon 182). The divorced claims her strong independence in Act One; however, in Act Two she unfolds the truth like the others in a close-up. She gets divorced when her ex-husband confronts her with the fact that she keeps denying his corruption to continue leading her luxurious life and enjoying the benefits of his position. In other words, she forces herself to live in an illusion of her own creation. In her disclosure to her husband, she is addressing herself as well.

The divorced: I'm sorry.. Sorry for lacking enough courage to confront you and myself.. Sorry for continuing to live with you all of those years and I know the truth.. Sorry for indirectly taking part in your corruption throughout.. It's true that I didn't know everything, but this was simply because I didn't want to know or to see or even to understand.. But now I can't go on.. No..No.. I can't live the illusion any more.. I can't.. I can't.

(WM 237)

The divorced is afraid of her inability to live in the true world because she is accustomed to the illusionary one, and this is her dilemma. She reveals her fears to the authoress and the other female characters "I'm afraid that after leaving my place in the illusion, I can't find another in reality" (WM 237). The details provided by the divorced "make the spectator grasp the actors' facial expressions, underline their gestures, and mark their dramatic function, all by the inclusion of a close-up" (Aumont 229).

\subsection{POV (Point of View)}

POV shots are the shots viewed by the spectator from the point of view of the character. In both plays, narrations are delivered by the female characters from their own points of view; in other words, the audience is exposed to a single experience provided by every character. As a technical term in film industry, POV is defined as "a camera concept which describes what is seen by the camera. Where one puts the camera and what the camera sees defines the frame and the image" (Cicekoglu 125).

In Top Girls, Act Three, Marlene and Joyce are engaged in a debate and a series of accusations. Through Joyce's narration of past memories from her point of view, the audience understands the reason for 
her exasperation towards her sister. Marlene got pregnant at an early age and could not get rid of her child, so she gave Angie up to Joyce. From Joyce's point of view she did not have any alternatives: who would raise up the child then if she did not adopt her? Joyce lost her own baby, after three years of marriage, because she had to take care of little Angie, "Listen when Angie was six months I did pregnant and I lost it because I was so tired looking after your fucking baby..../ because she cried so much- yes I did tell.../ you-....../ and the doctor said if I'd sat down all day with.../ my feet up I'd 've kept it/ and that's the only chance I ever had...." (TG 135).

In Without Masks, the widow narrates another dilemma: she has promised her husband not to remarry after his death and to remain a widow devoted to raising up her children. According to the norms of the patriarchal society, a widow has to remain faithful to her deceased husband to be highly estimated by the society. However,

El 'Assāl's widow fails to keep her promise and she secretly gets married to her neighbor. Two points of views are presented in this scene that of the widow who could not dare defy the social norms openly and another of the authoress who explains the widow's hidden problem.

The widow: I can't deny the fact.. Nights are long.. And I feel lonely especially after my children grew up and got married.. But still I couldn't tell them that I remarried...

The authoress: You want to live happily with your lover; this is absolutely your right because you are a human being and alive, not dead! However, at the same time you want others to point at you saying 'this is the great woman who sacrificed her youth and life for the sake of her children;' 'the one who fulfilled her promise to her husband and buried her youth in the same tomb.'... Both.. you want both" (WM 227).

The widow wants to satisfy her society even at the expense of her humanity. Therefore, she could not tell her children, now grown ups, that she has got married. She keeps her marriage a secret as if she is ashamed of such action. In other words, though a woman, the widow adopts the standards of her patriarchal society and believes in its oppressive norms. Through ages the weakness of woman's body is regarded as the main reason for the social outlook that she has to stay at home, and that her role is confined to "cooking, washing, mending.../Better than reading books" as Isabella Bird claimed in the opening scene of Top Girls (58). Her slave-like duties are far more important than enriching her intellectual abilities or considering herself as a human being equal to man. This condition is further fostered by social oppression "humiliation and underestimation...[is] the point which empowered men and gave them more confidence in their physical abilities and natural functions. Man thought that he was positioned to possess and protect woman because of her weakness and that woman was destined to be under his rule" (Ben Fradj 37).

\section{Conclusion}

Both Churchill and El 'Assāl depict a host of female characters to reinforce the oppressive tactics of their patriarchal societies. This study examines the 
techniques employed by both playwrights to portray the sufferings of their females through visual narration that demands audience participation. In other words, they manage to shift the audience's role from being a passive recipient to an active participant. The paper has attempted to examine the techniques of both dramatists adopting the approach of Semiotics, relying on two aspects of sign system: verbal and non-verbal signs. To achieve this aim the paper has explored two relevant techniques: Brecht's V-effect regarding the violation of time and space limitations and the employment of both overlapping dialogues as well as body language, in addition to the cinematic techniques of close shot and POV. The writer of the present paper has also found an interesting use of collage, a technique used in visual art that can be subject to further examination of the plays.

The theatrical and cinematic techniques contribute to altering the perceptions of the spectators and engaging them throughout the theatrical experience. Therefore, the plays end sending a strong message to the audience to confirm the role of perception and participation, as Brecht's final words in The Good Woman of Setzuan, "We see the curtain closed, the plot unended. In your opinion, then, what's to be done? Change human nature or the world? (106). In Churchill's play the message is implied in Angie's final scream; whereas in El 'Assāl 's it is stated explicitly by the characters on stage. In other words, the spectators of both plays are provoked with the aim of reconsidering the patriarchal oppressive norms imposed by their societies.

\section{Notes}

1 Caryl Churchill Top Girls is referred to in the in-text-citations as $(T G)$

2 Fathịyah El 'Assāl Without Masks is referred to in the in-text-citations as $(W M)$

3 Translation of excerpts from El 'Assāl 's play is done by the present writer 


\section{Works Cited}

Aston, Elaine. "Feeling the Loss of Feminism: Sarah Kane's Blasted and an Experiential Genealogy of Contemporary Women's Playwriting." Theatre Journal, Vol. 62, No. 4, 2010, pp. 575-591.

---. "Telling Feminist Tales," Feminist Views on the English Stage: Women Playwrights, 1990-2000. Cambridge University Press, 2003.
---. (The Picasso of Modern British Theatre) http://eprints.lancs.ac.uk/79872/1/Methuen_CC_essay_for_Darren.pdf Accessed 12 May 2018

Aumont, Jacques et.al. Aesthetics of Film, trans. Richard Neupert. University of Texas, 1992.

Ben Fradj, Nodhar Hammami. "The Female Body in the Nineteenth Century: from a Source of Humiliation to a Means of Liberation." Al-Mukhatabat Journal, Issue April, 2004, pp. 36-51.

Brecht, Bertlot. Brecht on Theatre, edited and translated by John Willet. Eyre Methuen, 1973.

Brown, Janet. "Caryl Churchill's Top Girls Catches the Next Wave." Caryl Churchill: A Casebook. Ed. Phyllis R. Randall. Garland, 1988, pp. 117-129.

Bryant-Bertail, Sarah. Space and Time in Epic Theatre: The Brechtian Legacy. Camden House, 2000.

Butler, Judith. Bodies that Matter: On the Discursive Limits of Sex. Routledge Classics, 2011.

Cambre, Maria-Carolina. "Immanence and Collage Heuristics." Visual Arts Research, Vol. 39 , No. 1 , summer 2013, pp. $70-89$.

Cameron, Rebecca. "From Great Women to Top Girls: Pageants of Sisterhood in British Feminist Theatre." Comparative Drama, Vol. 43, No. 2, 2009, pp. 142-166.

Carlson, Marvin. Theories of the Theatre: A Historical and Critical Survey from the Greeks to the Present. Cornell University Press, 1993.

Churchill, Caryl. Top Girls. Samuel French Inc. 1982.

Cicekoglu, Feride. "Difference, Visual Narration, and Point of View in My Name is Red." The Journal of Aesthetic Education, Vol. 37, No. 4, 2003, pp. 124-137.

Coman, Alice et.al. Collective Memory from a psychological Perspective. Springer Science and Business Media, 2009. 
Davis, Nathaniel. "Not a Soul in Sight": Beckett's Fourth Wall." Journal of Modern Literature, 2015.

Diamond, Elin. "Bodies in Churchill's Theatre." Theatre Journal, Vol. 40, No. 2, 1988, pp. 188-204.

---. "Brechtian Theory/ Feminist Theory: Toward a Gestic Feminist Criticism." TDR, Vol. 32, No. 1, 1988, pp. 82-94.

---. Unmaking Mimesis: Essays on Feminism and Theatre. Routledge, 1997.

Eder, Donna. "Building Cohesion through Collaborative Narration." Social Psychology Quarterly, Vol. 51, No. 3, 1988, pp. 225-235.

Elam, Keir. The Semiotics of Theatre and Drama. Routledge, 1980.

El 'Assāl, Fathīyah. Women Without Masks. GEBO, 1999.

Epp, Garrett P. J. "Visible Words: The York Plays, Brecht, and Gestic Writing." Comparative Drama, Vol. 24, No. 4, 1990, pp. 289-305.

Fortier, Mark. Theory/Theatre: An Introduction. Routledge, 2002.

"Gerry Charm Mandarin Artist's Life is a Visual Collage." The Florida Times Union. Sep. 7, 2010. https://www.questia.com/read/1G1-236838967/gerry-charm-mandarinartist-s-life-is-a-visual-collage Accessed 27 March 2018.

Gombrich, Ernest. "Moment and Movement in Art," The Image and the Eye. Phaidon, 1982, pp. 40-41.

Heddon, Dee. "Beyond the Self: autobiography as dialogue." Clare Wallace, ed. Monologues: Theatre, Performance, Subjectivity. Litteraria Pragensia, 2006, pp. 157-184.

Holl, Ute. Cinema, Trance, Cybernetics. Amsterdam University Press, 2017.

https://www.princeton.edu/ acoman/Publications_files/Coman\%20et\%20al.\%20\%282009 \%29-IJPCS.pdf Accessed 28 April 2018.

Jordan, Eamonn. Dissident Dramaturges: Contemporary Irish Theatre. Irish Academic Press, 2010.

Kelly, John C. "Cinematic." Studies: An Irish Quarterly Review, Vol. 53, No. 212, 1964, pp. $420-438$.

Keyssar, Helene. "The Dramas of Caryl Churchill: the Politics of Possibility." The Massachusetts Review, Vol. 24, No. 1, 1983, pp. 198-216.

King, Jay M. Rifts in Time and Space: Playing with Time in Barker, Stoppard and Churchill. Dissertation, Florida State University, 2004.

Konecni, Vladimir. "Psychological Aspects of the Expression of Anger and Violence on the Stage." Comparative Drama, Vol. 25, No. 3, 1991, pp. 215-241. 
Kritzer, Amelia Howe. The Plays of Caryl Churchill: Theatre of Empowerment. St.Martins, 1991.

Kurdi, Maria. "Narrative Drama: The Example of Contemporary Irish Playwrights." Hungarian Journal of English and American Studies, Vol. 16, No. 1/2, 2010, pp. 225-241.

Marohl, Joseph. "De-realised Women: Performance and Identity in Top Girls." Modern Drama, no. 30, 1987, pp 376-88.

Moore, Sonia. The Stanislavski System. Viking, 1960.

Peacock, Keith. Thatcher's Theatre: British Theatre and Drama in the Eighties. Greenwood Press, 1999.

Raaberg, Gwen. "Beyond Fragmentation: Collage as Feminist Strategy in the Arts." Mosaic: An Interdisciplinary Critical Journal, Vol. 31, No. 3, September 1998, pp. 153-171.

Richardson, Brian. "Unnatural Narration in Contemporary Drama." Unnatural Voices: Extreme Narration in Modern and Contemporary Fiction. Ohio State University Press, 2006, pp. 106-113

Schrader, Paul and Robert Brink." The Close-Up." Film Comment, Vol.50, No.5, 2014, 5861.

Seedat, Fatima. "Islamic Feminism: Between Inadequacy and Inevitability." Journal of Feminist Studies in Religion, Vol. 29, No. 2, 2013, pp. 25-45.

Segre, Cesare and John Meddemmen. "Contribution to the Semiotics of Theatre." Poetics Today, Vol. 1, No. 3, 1980, pp. 39-48.

Selaiha, Nehad and Sarah Enany. "Contemporary Women Playwrights." Theatre Journal, Vol. 62, No. 4, Dec.2010, pp. 627-643.

Silberman, Marc. "Bertolt Brecht: Politics and Comedy." Social Research, Vol. 79, No. 1, 2012, pp. 169-188. 